\title{
Thermal Storage Applications Workshop
}

Held at Golden, Colorado

February 14-15, 1978

\section{Volume I - Plenary Session Analysis}

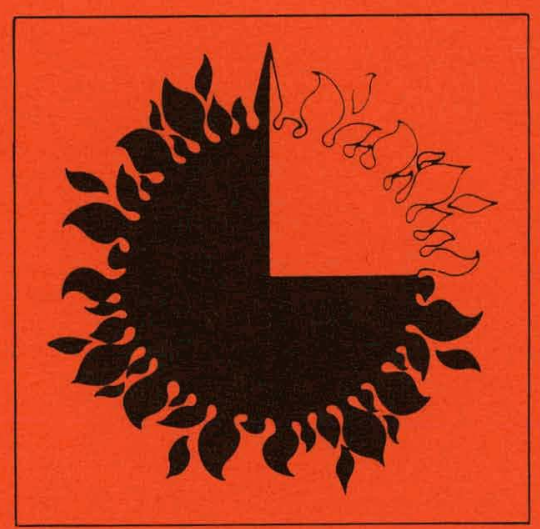

February 15, 1979

Prepared for

U.S. Department of Energy

by

Jet Propulsion Laboratory

California Institute of Technology

Pasadena, California

(JPL PUBLICATION 79-8, VOLUME I) 


\section{DISCLAIMER}

This report was prepared as an account of work sponsored by an agency of the United States Government. Neither the United States Government nor any agency Thereof, nor any of their employees, makes any warranty, express or implied, or assumes any legal liability or responsibility for the accuracy, completeness, or usefulness of any information, apparatus, product, or process disclosed, or represents that its use would not infringe privately owned rights. Reference herein to any specific commercial product, process, or service by trade name, trademark, manufacturer, or otherwise does not necessarily constitute or imply its endorsement, recommendation, or favoring by the United States Government or any agency thereof. The views and opinions of authors expressed herein do not necessarily state or reflect those of the United States Government or any agency thereof. 


\section{DISCLAIMER}

Portions of this document may be illegible in electronic image products. Images are produced from the best available original document. 


\title{
Thermal Storage Applications Workshop
}

\author{
Held at Golden, Colorado
}

February 14-15, 1978

\section{Volume I - Plenary Session Analysis}

February 15, 1979

Prepared for

U.S. Department of Energy

by

Jet Propulsion Laboratory

California Institute of Technology

Pasadena, California

(JPL PUBLICATION 79-8, VOLUME I)
This report was prepared as an account of work sponsored by the United States Govemment. Neither the United States nor the United Stales Depaitiuitut of Energy, nor any of their employees, nor any of their

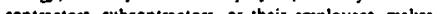
any warrany, express or implied, or aseyes, livbility or responsibity for the accuracy, cos ple

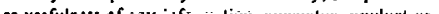

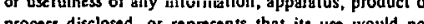
process dissered, or represents that its use would not infringe privately owned tights. 
Prepared by the Jet Propulsion Laboratory, California Institute of Technology, for the U.S. Department of Energy by agreement with the National Aeronautics and Space Administration.

This report was prepared as an account of work sponsored by the United States Government. Neither the United States nor the United States Department of Energy, nor any of their employees, nor any of their contractors, subcontractors, or their employees, makes any warranty, express or implied, or assumes any legal liability or responsibility for the accuracy, completeness or usefulness of any information, apparatus, product or process disclosed, or represents that its use would not infringe privately owned rights. 
On February 14 and 15, 1978, a workshop on solar power development and thermal and thermochemical energy storage technology was held at Golden, Colorado. The meeting was sponsored by the United States Department of Energy and organized by the Jet Propulsion Laboratory.

These proceedings contain the record of this workshop. They are divided into two volumes. Volume $I$ presents an analysis and condensation of information discussed in round-table plenary sessions. Volume II consists of the papers presented at the workshop, as submitted. 
THIS PAGE

\section{WAS INTENTIONALLY \\ LEFT BLANK}


CONTENTS

I. EXECUTIVE SUMMARY

II. PLENARY SESSION ANALYSIS - SUMMARY AND CONCLUSIONS OF INTERACTIVE SESSIONS -

A. SESSION 1. STORAGE IN CENTRAL POWER APPLICATIONS --

B. SESSION 2. STORAGE IN DISPERSED POWER APPLICATIONS -- 2-4

C. SESSION 3. PROBLEMS ASSOCIATED WITH DEVELOPMENT OF STORAGE SYSTEMS FOR SOLAR POWER APPLICATIONS --_--- 2-7

D. SESSION 4. WRAP-UP INCLUDING CONCLUSIONS AND

PLAN OF ACTION -

III. WORKSHOP AGENDA - 3-1

IV. WORKSHOP PARTICIPANTS - 
SECTION I

STORAGE APPLICATIONS WORKSHOP

EXECUTIVE SUMMARY

On February 14 and 15, 1978, 30 people from nine organizations involved with solar power development and thermal and thermochemical energy storage technology met at Golden, Colorado for a workshop. The purpose of the workshop was to provide both information exchange and planning for future storage technology development and its impact on the solar thermal power program. Represented organizations included: Department of Energy, Jet Propulsion Laboratory, Aerospace Corporation, Lewis Research Center, Sandia Livermore Laboratory, Sandia Albuquerque Laboratory, Oak Ridge National Laboratory, Solar Energy Research Institute, and Electric Power Research Institute.

The meeting was divided into two different types of sessions. During the first half of the workshop, fourteen reports were presented. These included overview papers for various programs and technologies and papers describing specific technical points related to interfacing energy storage with solar power plants. The second half of the workshop consisted of four plenary sessions in which everyone participated.

The Workshop Proceedings are divided into two volumes. Volume I is an analysis of the plenary sessions. Volume II contains the individual papers.

During the plenary sessions it was agreed that development of inexpensive and efficient storage is essential to the solar thermal power programs. Suitable storage systems are not now available, so more technology development and demonstrations are needed. Dispatch studies and mission analysis studies can be deemphasized, since for first generation solar power plants the maximum benefit due to storage probably accrues using 3 to 6 hours of storage, and this is not the time for fine-tuned optimization. Although some sensible heat storage systems have been demonstrated, latent heat systems are not yet available for large demonstration units. High temperature $\left(1500^{\circ} \mathrm{F}=815^{\circ} \mathrm{C}\right)$ large scale storage technology requires

long-term development, and needs much more emphasis in STOR's program plans.

Several dispersed solar power installations exist, including irrigation units, but $12 \mathrm{ck}$ of high temperature storage has restrictd overall system designs to low temperatures and low conversion efficiencies. Even if storage units were free, there is maximum practical storage duration, since more storage capability necessitates more expensive collector fields for charging. Present 
estimates of this maximum duration range from 20 to 100 hours. Most planned demonstration units will have full electrical backup. The industrial sector is an attractive market for dispersed power systems.

In the past, a communications problem has existed between the Storage Development Program (STOR) and Solar Thermal Power applications teams. The applications people need technology support from the storage labs, but have trouble identifying what is available or realistically achievable in the storage area. Conversely, STOR needs priorities and requirements because they are developing high-risk, long-term technology and have difficulty identifying specifications or requirements in the solar thermal area because both are continually changing.

Application labs issuing requests for proposals (RFPs) on Solar Power Projects should collaborate with STOR, so the RFP might list suggested storage units with specifications which could be used. The respondent could use one of the suggested storage units rather than have to develop his own storage unit. The major effort could then go to the respondent's area of expertise, and contractors would thus be stimulated to use available developed techniques.

Iterations between STOR and the application labs are necessary. A Planning Committee for thermal and thermochemical storage and solar thermal power applications has been formed. The membership in the Committee consists of one senior individual cognizant of each program within each center. LeRC leads the coordination effort for STOR, and a LeRC representative will visit each application center to determine the storage needs of each $1 \mathrm{ab}$ and also to advise what storage systems with given capabilities are available. This will be a continuing activity.

The annual thermal storage contractors meeting is a good place to review the state of present thermal storage technology. The consensus was that the joint Solar Thermal Power/STOR Workshop on thermal storage for solar thermal power systems had been informative and productive, and a similar workshop should be held again next year. 


\section{PLENARY SESSION ANALYSIS - SUMMARY AND CONCLUSIONS OF INTERACTIVE SESSIONS}

\section{A. SESSION 1. STORAGE IN CENTRAL POWER APPLICATIONS

\author{
Chairmen: Lee Radosevich (Sandia-L) and Pat Eicker (Sandia-L)
}

Sandia Livermore $\mathrm{Lab}$ is the government facility responsible for development of central receiver solar electric power technology. They are managing the contract for the central receiver pilot demonstration to be built in Barstow in 1980. Three companies competed for this contract, and each team designed and began development on a thermal storage subsystem. The McDonnel1-Douglas (McDAC) oil and hot rock approach was selected because it cost the least when integrated into its complete power system. For the $1.0 \mathrm{MW}-\mathrm{e}$ demo plant, the storage system is designed to provide $7 \mathrm{MW}-\mathrm{e}$ for three hours, and for the commercial solar power plant the storage capability should be $70 \mathrm{MW}-\mathrm{e}$ for six hours. It was pointed out that a more efficient storage system allows deployment of fewer heliostats in the collector fields, manifesting as a bonus for economic accounting in a comparative assessment. This storage effect on the entire system was considered in the selection analysis. Since the storage component has a relatively small cost compared to the entire solar power plant, large improvement in storage development would improve the entire system cost-benefit ratio only incrementally. But it was forcefully stressed that a very small improvement in power plant efficiency will amount to billions of dollars in savings when considered over many plants for many years, and that electric utilities spend considerable sums attempting to improve power plant efficiencies by $0.1 \%$. Therefore, storage development is of critical importance to the solar thermal power program.

It was agreed that one cannot treat a storage subsystem as a black box independent of the system it supports, and that a system which works well in one application could be a poor performer in another.

A request for proposal (RFP) will be issued by the DOE Department of Solar Thermal to research and design an advanced water/steam solar power plant which will operate at higher temperatures and pressures than the Barstow demo plant. There was some concern that if a suitable thermal storage unit is not already developed, then some of the same problems which manifested during the Barstow development could again irritate the project. The thermal conversion efficiency of the Barstow plant, using steam direct off the receiver, is expected to be $32 \%$. This might be compared to a conventional boiling superheating power steam plant with superheating to $1050 \%$ and efficiency of $36-38 \%$, or the best supercritical steam power plant with efficiency of $40 \%$. Stack 
cleanup and boiler losses hurt coal plant efficiencies. With present-day designs for solar power plants and storage units, dual admission turbines are required, one port for operation from storage and the other for direct reception of steam from the receiver.

The Lewis Research Center (LeRC) is the government lab responsible for development of high temperature thermal storage, for a variety of applications. The total LeRC storage budget is around $\$ 2$ million. About $\$ 0.5$ million is being directed toward development of latent heat systems. It was pointed out that with active heat exchangers, e.g., a tube containing transport fluid surrounded by a phase change material (PCM), about half of the system cost is for the heat exchange tubes. If the problem of PCM freezing on tubes can be overcome, then this would significantly affect the economics of this type of system. Improvements in this area are being pursued, but large-scale latent heat systems are not yet technically feasible; they are still in the laboratory development stage. However, studies indicate that latent heat systems are potentially more economical than sensible heat storage for power plants.

The problems of integrating a thermal storage unit (TSU) into a solar power plant are more severe than for a conventional power plant. For a conventional plant, only a fraction of the total thermal input or output is going into or from storage at a given time; and in a solar system, high temperature backup is also lacking. Furthermore, the temperature level at which a solar plant is designed can determine whether sensible or latent heat storage is more apppropriate with currently available technology. A Boeing study (for a solar Brayton system with temperatures to $1500^{\circ} \mathrm{F}$ ) showed that the considered latent heat storage system cost about one-third of a sensible heat storage system. The sensible heat storage system considered in the Boeing study features a pressure vessel with interior insulation and magnesium oxide bricks as the storage medium. But these high temperature systems (1500\%) are far term technology, at least 15 years away; for today's designs, sensible heat storage systems appear to be more appropriate for lower temperature solar power plants.

One caveat for decision makers is to carefully scrutinize storage system cost estimates early in the conceptual stage, since real system costs are often not recognized or severely underestimated. That is, new technologies often look better than existing competitors because the problems have not yet been identified - the inverse law of ignorance. In many systems, storage material costs can be ten to twenty percent of the total system cost, with tankage, heat exchangers, and other necessary items making up the rest. Even less obvious is the impact of life cycle cost, where a system characterized by low. first cost but relatively low efficiency may be a poor selection. Right now it appears that no applications laboratory has specific cost goals for storage.

One of the contributed papers from the morning session indicated that seasonal storage for solar power plants makes no sense anywhere in the country. It appears that the range between three and seventeen hours is probably best. 
It was suggested that no more dispatch strategy or mission analysis studies are needed, because in any case the answer will likely be between three and six hours of storage for a solar power plant. More technology development and demonstrations are needed, rather than optimization analyses, because what is optimum now will not be so in the year 2000. Also, it is a mistake to expect solar power to be economically competitive now; as a contingency for the future, solar plants should be built to gain operational experience. Therefore, there is little need for comparative assessments against existing non-solar sources or even against other clean, new, non-solar energy sources.

It is possible that thermal storage in a solar power plant may not be desirable (other than for half-hour thermal buffering against occasional cloud occlusion). Perhaps, also, a solar plant should not be expected to stand on its own, but should be integrated with other systems so that each can serve as backup for the other(s), since in any case a solar power plant has to be optimized to integrate into a total electrical utility network Eventually, storage of some sort will be needed to fully utilize energy from the sun, but in the near term one can get capacity credit at low penetration levels for solar systems where load is coincident with insolation without the storage.

On the other hand, since a solar power plant needs buffer storage for technical reasons, much of the power-related costs are already paid if some kinds of storage systems (especially sensible heat systems) are used. Therefore, in many cases, addition of more storage capacity (not power capacity) is relatively cheap, since the power-related cost can essentially be considered a sunk cost. More thinking is needed in this area. But in any case, if the present goal is to demonstrate solar thermal power technology, then the optimal storage requirement can be deferred. For the Barstow 10 MW-e demo plant, the size of the thermal storage unit has not yet been selected. But it has been established that the curve of electricity cost versus hours of storage is relatively flat between three and seven hours of storage. A number of people using different ground rules and algorithms have come to the same conclusion.

There appears to be a circular problem between the storage development people (STOR) and the solar power development teams. On the one hand, the solar people need technology support from the storage labs, but have difficulty advencing specifications or even size requirements. Part of this difficulty is not knowing what is realistic, achievable and even available, both technically and economically. Another problem is that requirements are continually changing. STOR is developing high risk, long term R\&D lechnology independent of solar thermal needs, but enough flexibility exists in the present program to include specific areas. STOR needs priorities. Iterations between the two groups will be necessary. It was decided by STOR to assemble a list of available storage technologies and systems with characteristic parameters and supply them to the applications laboratories so they would be aware of the existing alternatives. 
The area of technology development which needs the greatest attention is high temperature storage, up to $1500^{\circ} \mathrm{F}$. No hightemperature storage technology work is in progress or even planned. If there is serious interest in solar thermal power at these temperatures, for example Brayton power cycles operating at $1500^{\circ} \mathrm{F}$, the appropriate storage research must be planned now. Even if electrical storage is contemplated for such systems, some thermal storage is still required for the plant to handle occasional transients, and the same technology is probably required whether we build in one-half hour of storage for buffering or eight hours. It may be that sufficient thermal inertia can be built into some high-temperature systems to keep them going through occasional cloud passover, but the transient problem is an area where more study is needed. No one indicated that study was in progress to determine the minimum amount of thermal inertia storage that ought to be incorporated into solar power plants. This reflects on the circular problem of priorities and commitments mentioned above, i.e., that STOR cannot continue studying high temperature storage until there is a demonstrated need. The applications people would like to increase their options by having available technology with which to design, but they do not know what is available or attainable. By the time the applications people need advanced storage technology, they cannot wait for its development. It might be better for STOR to continue general development so fallout is available downstream. If there were a definite requirement for high temperature storage, then STOR could initiate development of a latent heat storage unit using fluorides, which have been shown to offer potential for the lowest cost thermal storage unit.

\section{B. SESSION 2. STORAGE IN DISPERSED POWER APPLICATIONS}

Chairman: Jim Rannels (Dispersed Applications Power Project, DOE )

The session started out with a slide presentation by Jim Rannels.

Small dispersed power systems have a definite need for energy storage subsystems; lack of appropriate technology is a concern. There are several existing hardware installations, including irrigation systems. For an irrigation demonstration at Willard, New Mexico, characteristics of the storage system limited the maximum temperature of the solar system and power cycle, which is an organic Rankine cycle with R-113 fluid. An oil with advancing thermocline TSU was selected. It has a maximum allowable temperature of $450^{\circ} \mathrm{F}$, and this limited options on the rest of the system, driving down temperatures and conversion efficiency. As with large central receiver solar power plants (discussed in Plenary Session 1), no need for seasonal storage is identified; storage requirements may range between four and forty-eight hours, but it is not a month. Although the economics of an irrigation unit may differ from some other applications, both have a pressing need for storage. 
For Willard, the economics are such that the system is tied into the local electric utility if the system's 12 hours of storage becomes depleted. But the practice of depending upon electrical backup could become unacceptable to the utility if solar installations become large and widespread; it is a question of overall network compatibility. Using electrical backup in a solar system requires an entirely different set of rate structures than has been traditional to match the cost of service to the consumer; often this is not recognized, but rates could increase. Normally, storage analyses have been based upon traditional utility loads. If it turns out that significant penetration of solar home heating units, solar hot water heating and other applications evolve regionally, and these people turn to utilities for backup, then new supply patterns and rate structures could ensue. Another alternative for backup for some systems would be to have some kind of fuel at the site, either synthetic or fossil, for combustion on those occasions when storage was depleted. And in the case of irrigation, for extended cloudy periods the need for output may decrease enough to tolerate interrupted service. Most of the experiments planned in the Dispersed Small Power Program have full electriçal backup. Units independent of a grid will have to wait.

In essence, electrical backup is a type of long-term chemical storage, since the electricity is generated from fossil fuel. This suggests that chemical fuels or even chemical storage might be an acceptable storage device for such applications. But more study is needed in this area.

A rough goal for acceptable storage cost of the Small Applications Power Project is $\$ 20 / \mathrm{kWhr}-\mathrm{e}$; presently, storage to $500^{\circ} \mathrm{F}$ is costing $\$ 60 / \mathrm{kWhr}-\mathrm{e}$, and the Project would like to see higher temperature levels. There is pessimism that improvements and mass production of the existing hot rock and oil technique will significantly reduce its cost, certainly not enough to meet the goal. This indicates that more storage technology development is needed. Some requirements are similar to the Central Receiver Program, but there are some differences. The Dispersed Power Applications Program would like to have STOR tracking them in terms of technology to develop storage devices lhal cau suppuit them in the temperature regimes within which they plan to operate. STOR should be a planning consultant to the Program. In this Program it is planned that temperature levels will increase with time, from the $450^{\circ} \mathrm{F}$ Willard facility to small central receivers at $1000^{\circ} \mathrm{F}$ to $1200^{\circ} \mathrm{F}$. In planning demonstrations, the tendency is to use what is available today. One difference between the Central Receiver Large Scale Power Program and the Dispersed Applications Program is that the small applications program anticipates using lots of thermal energy, as opposed lo generating only electricity.

Storage, whether expensive or inexpensive, requires more collectors which are generally dedicated to charging the TSU. With increased storage, both the storage unit and dedicated collectors have lower utilization factors and lower conversion efficiencies. 
Beyond a certain critical size of storage unit relative to collector and generator size, large storage units with more collectors thus have a lower cost-benefit ratio. Above the critical storage size, the cost of a marginal unit of installed storage, even if that storage were free, is driven primarily by the cost of the additional collectors installed to charge that unit. Generally, the first two hours of storage are extremely valuable, and they help displace the load. For some applications, the value of additional storage drops dramatically after about four hours, until at 10 hours it is probably not worth anything at all. In this case, it is probably better for the operator to just shut down until solar input is again available.

Storage capacity beyond the critical size represents an insurance premium which allows uninterrupted operation. In many Sun Belt locations where there are no long periods of solar outage and disrupted operation would be undesirable, it may be better to have a conventional fuel backup system, regardless of fuel cost, rather than provide storage (and additional collectors) for the few days each year when they would be used. For most applications, very few people seriously think that solar stand-alone plants for continuous output without backup of some kind makes sense; the cost of the additional storage and collectors (which have a minimum utilization factor) is just too great for the added benefit.

The Small Applications Project has done several market analysis studies in each of the sectors of interest: irrigation, small power systems, and total energy systems. The aggregate conclusion is that for the dispersed power systems, there are at least six quads (one quad $=10^{15}$ BTUs $=3 \times 10^{8} \mathrm{MWhr}$ ) that solar power can displace from the national energy budget once the market is fully penetrated. The total market is probably on the order of 15 quads. In 1972 the total energy consumed in the United States was 72 quads.*

The industrial sector is one of the most attractive markets for dispersed power systems. The commercial market has some problems, as do the residential and institutional markets. The industrial market for energy runs around 30 quads per year, and over half of that is steam; however, there are many siting problems that exclude some industrial sectors from consideration, such as downtown areas which might require retrofits on roofs. The paper industry is an attractive market, even though it now gets around $40 \%$ of its energy from wood wastes.

The LeRC team pointed out that they are presently doing some storage work specifically in support of the dispersed power systems effort, namely development of a couple of systems. One is a sodium hydroxide $(\mathrm{NaOH})$ phase change system, appropriate for temperatures to $260^{\circ} \mathrm{C}\left(500^{\circ} \mathrm{F}\right)$, which uses a static heat exchanger tube bundle. A small-scale model has been constructed and is being tested at Sandia-Albuquerque, and money is budgeted to construct a larger-scale

\#SOURCE: FEA "Project Independence Blueprint", November, 1974. 
system. There has been close cooperation between technical personnel at LeRC and Sandia-A; problem areas are primarily programmatic. A second system being developed is the encapsulated phase change medium concept of the Naval Research Lab (NRL) which uses a chemical heat pipe approach for thermal input and extraction. The expected temperature level for this unit is up to $450^{\circ} \mathrm{C}$ $\left(842^{\circ} \mathrm{F}\right)$. By the third quarter of calendar year 1979 , LeRC will have built and tested two fairly large-scale hardware systems storing energy on the order of megawatt-hours. Furthermore, every application area can expect spinoff storage technology from a variety of systems that are being developed on paper, including trickle storage hot rocks and oil units.

A major problem appears to be lack of cross-communication between STOR and the applications labs. There should probably be an internal mechanism within the solar program to allow the labs to keep abreast of various STOR developments, so the two programs are consistent. Perhaps a single person at each of the applications labs should have responsibility for tracking STOR's program and providing inputs and requirements requests.

When the solar applications labs issue RFPs for experimental solar power plants, each proposer is normally asked to develop every component of his system, including a storage unit. Many respondents have to start from a position of near total ignorance in the storage area, rather than taking advantage of technology which has already been developed. It would make sense for the $1 \mathrm{ab}$ issuing the RFP to collaborate with STOR and make available a list of suggested storage systems with specifications, which the responding contractor hopefully could lift directly, rather than attempt separate development. Then he could focus more on other parts of the system with which he may have greater expertise. The storage concepts on the approved list would have a far greater degree of development than would the storage unit concepts that most contractors would advance. This would stimulate contractors to apply technologies that are available.

\section{SESSION 3. PROBLEMS ASSOCIATED WITH DEVELOPMENT OF STORAGE SYSTEMS FOR SOLAR POWER APPLICATIONS}

Chairmen: Jim Calogeras (LeRC) and Bill Masica (LeRC)

The role of SERI in solar R\&D is still unclear, particularly how they can contribute to the efforts of the storage development people (STOR). Part of SERI's immediate problem is to define their function in the solar program with respect to the other labs. In the storage area, SERI might lean towards the longer-term storage applications, including thermochemical technology. Generally, SERI appears to be leaning toward development of longer-term technology.

STOR believes the applications people must narrow down the range of requirements before STOR can constructively participate in specific programs. For example, in Plenary Session 2, the distributed applications program cited temperature ranges from $450^{\circ} \mathrm{F}$ 
to $1200 \circ$, power levels from kilowatts to megawatts, and storage durations from two to twenty-four hours. There is a need to focus on certain areas of emphasis:. On what should STOR work? What is the real worth of thermal storage and what priorities do solar thermal applications teams assign to storage?

To develop a specific storage system research program and demonstrate a technology requires several years. Therefore, the solar applications people must commit themselves to needs before the storage development people can commit themselves to development. For example, is there interest in advanced power cycles, like Stirling engines, which might operate in the $1350^{\circ} \mathrm{F}$ to $1500^{\circ} \mathrm{F}$ range? STOR is not working on storage units suitable for such temperatures, and if they should be, they need to know specifications and schedules. Is there a need for high temperature buffer storage? Right now the temperature zone of $1000^{\circ} \mathrm{F}$ is receiving highest priority in terms of storage systems. Presently, the main focus at Lewis Research Center (LeRC) is on sensible heat systems, although some work is being done on phase change storage. If latent heat systems will ever compete, then improvements must be made in heat exchange technology.

To date, the work that has been done on dispersed power plants at high tempertures (1500\%) indicates that unless thermal storage can be made inexpensive, electrical storage is superior, despite inherent disadvantages.

It is obvious that continuing dialogue is going to be necessary, and the question is, how can this dialogue be established and maintained, in a mode most beneficial to DOE? This should most likely be done on a laboratory-by-laboratory basis between appropriate STOR and applications groups; iterations will be necessary. That way, the storage people can develop the big picture, and applications people will know what is available. In addition, periodic planning sessions are needed, involving key people from DOE and the various laboratories. With information thus gained, the planning group could look at the big picture and set priorities, within monetary constraints. LeRC would be a central focus for the first iteration for thermal storage, and ultimately Sandia-Livermore would also be involved for thermochemical storage. This overall process is probably the best way for decision makers to make the most informed decisions to produce optimum effects. It was emphasized that although LeRC would be the central focus for storage, each of the four or five applications centers would be responsible for gathering its own requirements. There would be no liaison who would coordinate all solar thermal application needs. 


\section{SESSION 4. WRAP-UP INCLUDING CONCLUSIONS AND PLAN OF ACTION}

Chairmen: Vince Truscello (JPL) and Bob Turner (JPL)

Membership for a Thermal Storage Planning and Coordination Committee which would essentially function as an interagency technical exchange was considered. The following suggestions for membership were advanced:

$\begin{array}{ll}\text { ORGANIZATION } & \frac{\text { MEMBER }}{\text { DOE-Applications }} \\ \text { DOE-APPlicatons } & \text { Marty Gutstein } \\ \text { DOE-STOR } & \text { Jim Rannels } \\ \text { LeRC } & \text { C. J. Swet/John Gahimer } \\ \text { JPL } & \text { Jim Calogeras } \\ \text { Sandia-Albuquerque } & \text { Vince Truscello } \\ \begin{array}{l}\text { Sandia-Livermore } \\ \text { (Applications) }\end{array} & \text { Jim Banas } \\ \text { Sandia-Livermore (STOR) } & \text { Lee Radosevich }\end{array}$

Jim Calogeras (LeRC) was to lead the coordination effort for the STOR people and would collect and analyze requirement information from the different labs. Within STOR, Calogeras will be cognizant of technical questions and needs. The goal is to establish a program $\mathrm{plan}$ which defines storage requirement goals and then aggressively pursues apppropriate R\&D to meet these goals. To this end, Calogeras is to visit the various application centers individually to determine requirements. It will be both a technical and programmatic interaction. It is premature for LeRC to 1 ist necessary storage system parameters, such as charge rates, temperature levels, etc. These must be supplied by the application labs. Although Taz Bramlette of Sandia-Livermore is the STOR man who knows about thermochemical energy storage, and thus the appropriate liaison in this area, he will not at this time conduct the same kind of survey. Calogeras' survey should be completed by mid-April, so that when annual planning is done in mid-May, the information will be available. Calogeras was to write a draft of his survey which will be sent to the liaison at each of the application centers for review and comments. Currently LeRC and S'TOR are formulating a five-year plan for FY 1980-1985. 
Formation of an advisory group to include all solar app1ications, such as low temperature storage for houses, etc., as well as high temperature applications, was discussed; it was decided that although such a committee might be feasible, it is not necessary from the present workshop. The National Research Council (NRC) organized a storage workshop in 1976 which had such a function, and today a National Academy of Sciences committee makes the recommendations to STOR about whether STOR programs are in fact satisfying the national need and how the programs should be modified. The group is composed of senior technical people. Another similar committee would be redundant.

It was pointed out that once a year, each STOR program conducts a Contractor's Information Exchange Meeting, where all contractors developing storage concepts convene for two or three days and present brief papers describing their work. This serves as a technology review for the field. It may make sense for personnel from the lead applications laboratories to sit in on these update meetings.

The consensus was that this Storage Applications Workshop had been productive and had provided the first formal interaction between the solar thermal people and the storage people. There was general agreement that the workshop should be held again next year under the same format, with a front-end data dump to describe recent R\&D and system studies, followed by a group interaction to interpret and exchange ideas and requirements. Several people suggested that if the meeting is held next winter, it should be held in a warmer climate than Colorado. 
FEBRUARY 13

Registration and Social, 7:30 p.m., Holiday Inn - Lounge Area FIRST DAY - FEBRUARY 14

(Note: Each paper is scheduled.for 20 minutes total time; 15 minutes for the paper and 5 minutes for questions.)

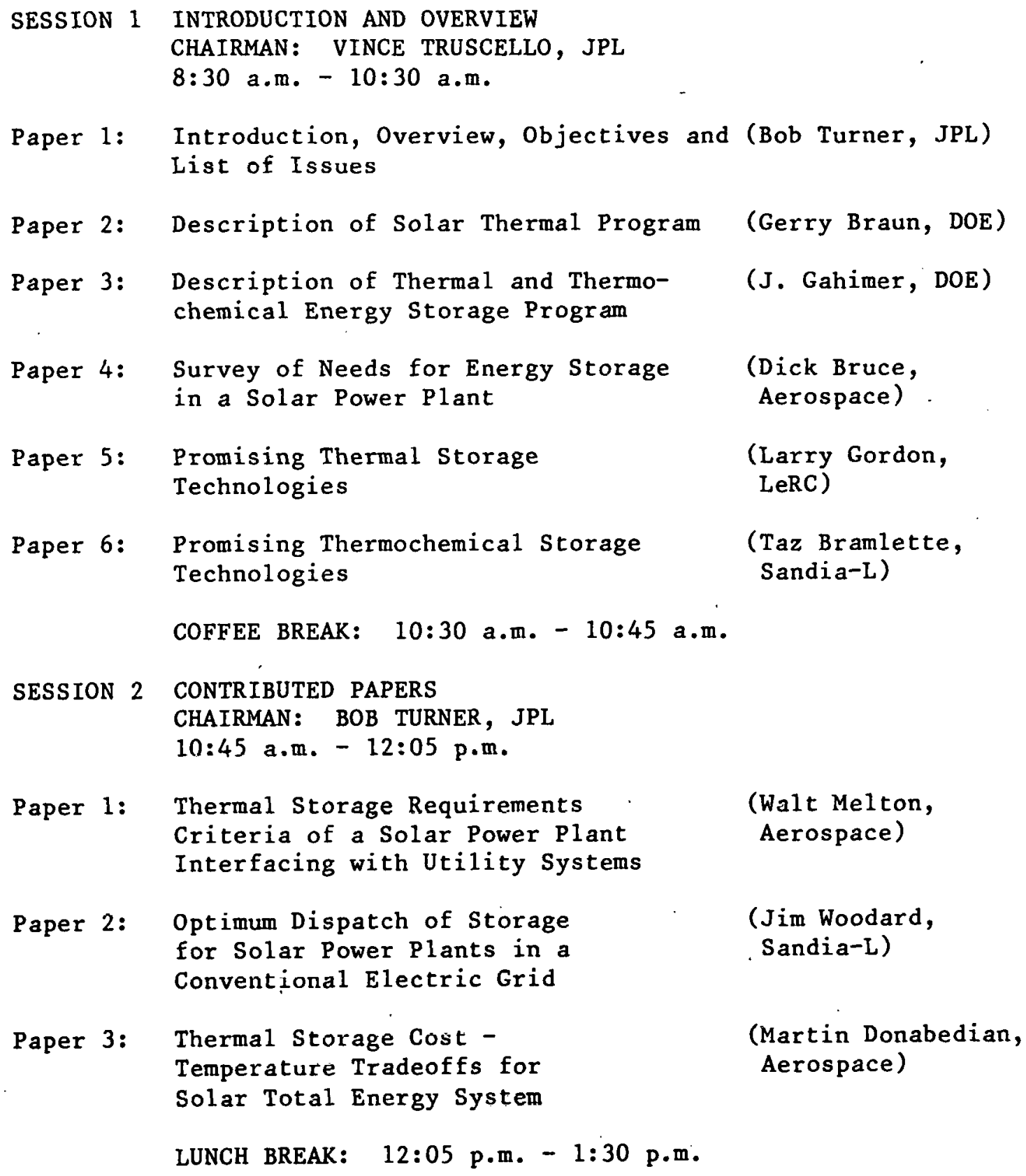

(Walt Melton, Aerospace)

(Jim Woodard, Sandia-L)

(Martin Donabedian, Aerospace) 


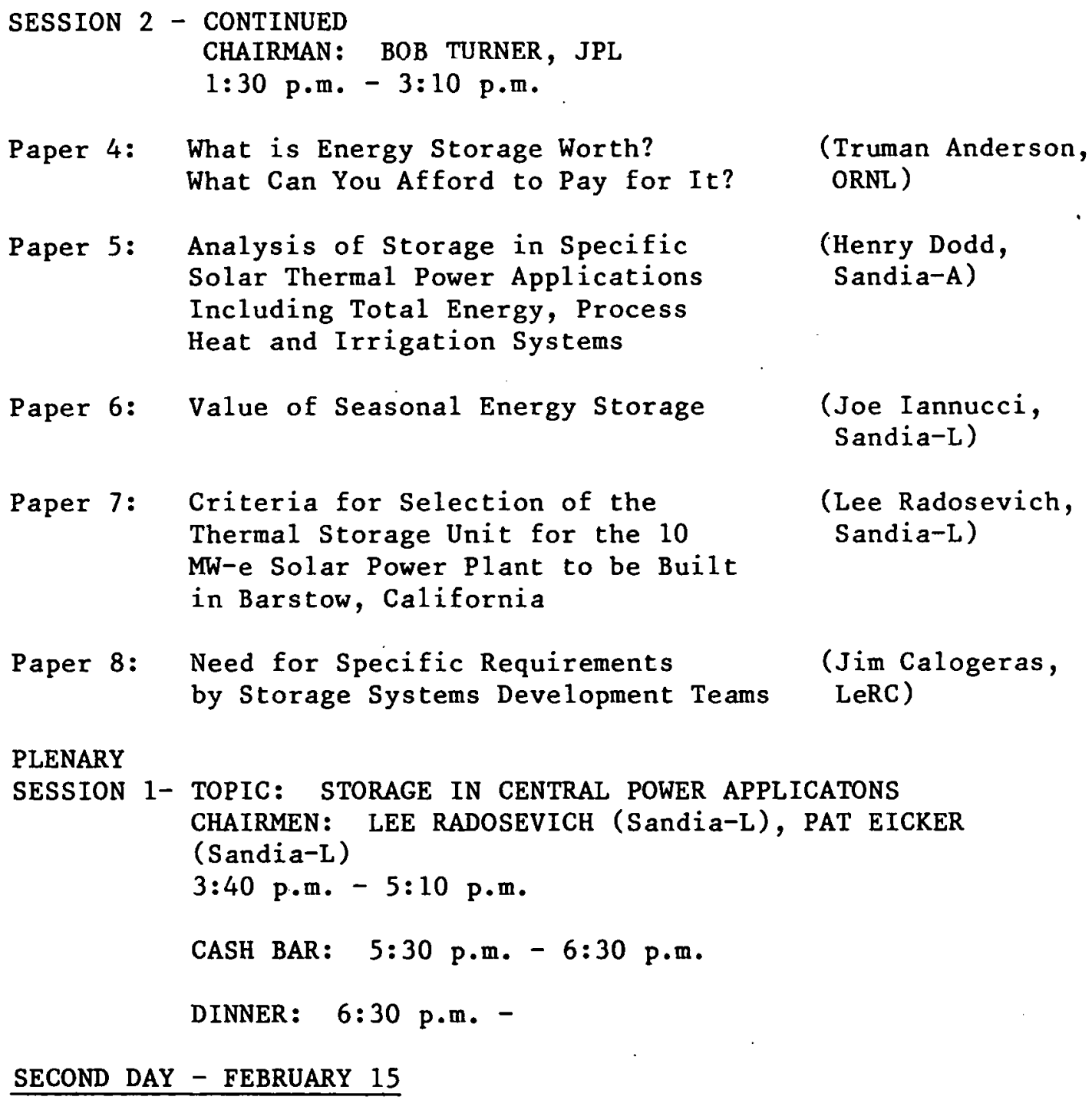

Paper 4: What is Energy Storage Worth?

What Can You Afford to Pay for It?

(Truman Anderson, ORNL )

Paper 5: Analysis of Storage in Specific

Solar Thermal Power Applications

(Henry Dodd, Including Total Energy, Process Sandia-A)

Heat and Irrigation Systems

Paper 6: Value of Seasonal Energy Storage

(Joe Iannucci, Sandia-L)

Paper 7: Criteria for Selection of the Thermal Storage Unit for the 10

(Lee Radosevich, MW-e Solar Power Plant to be Built Sandia-L)

in Barstow, California

Paper 8: Need for Specific Requirements

by Storage Systems Development Teams

( Jim Calogeras, LeRC)

PLENARY

SESSION 1- TOPIC: STORAGE IN CENTRAL POWER APPLICATONS CHAIRMEN: LEE RADOSEVICH (Sandia-L), PAT EICKER (Sandia-L)

3:40 p.m. - 5:10 p.m.

CASH BAR: 5:30 p.m. - 6:30 p.m.

DINNER: $6: 30 \mathrm{p} . \mathrm{m} .-$

SECOND DAY - FEBRUARY 15

PLENARY

SESSION 2- TOPIC: STORAGE IN DISPERSED POWER APPLICATIONS CHAIRMEN: JIM RANNELS (DOE), TRUMAN ANDERSON (ORNL)

$8: 30$ a.m. - 10:00 a.m.

BREAK: 10:00 a.m. - 10:30 a.m.

PLENARY

SESSION 3- TOPIC: PROBLEMS AND CRITERIA ASSOCIATED WITH DEVELOPMENT OF STORAGE SYSTEMS FOR SOLAR POWER APPLICATIONS

CHAIRMEN: BILL MASICA AND JIM CALOGERAS (LeRC)

$10: 30$ a.m. - 12:00 p.m.

LUNCH: $12: 00$ p.m. $-1: 00$ p.m. Catered cold cuts, cokes, coffee in Holiday Inn - Lounge Area

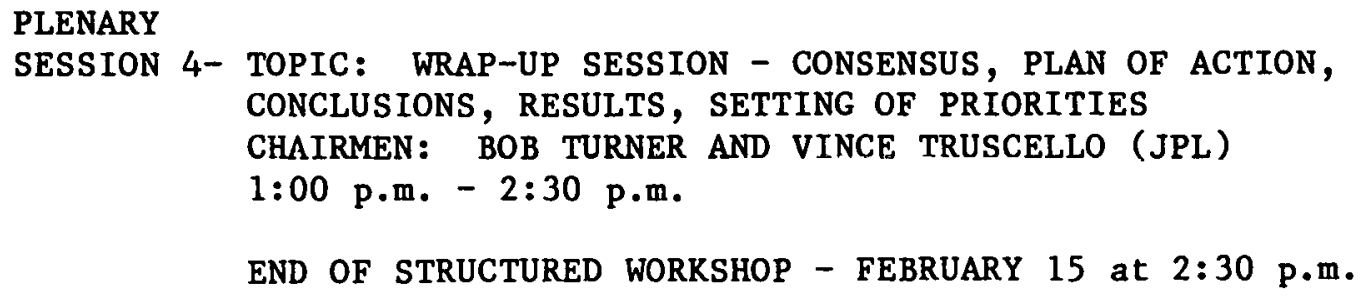


SECTION IV

WORKSHOP PARTICIPANTS

FEBRUARY 14-15, 1978

Truman D. Anderson

Oak Ridge National Laboratory P. O. Box $Y$

Oak Ridge, TN 37921

615-483-8611 x35698

John Bigger

EPRI

P.0. Box 10412

3412 Hillview Ave.

Palo Alto, CA 94303

415-493-4800

Charles J. Bishop

SERI

1536 Cole Blvd.

Golden, CO 80401

303-234-7121 (FTS 327-7121)

T. Tazwe11 Bramlette

Sandia Livermore Laboratories

East Avenue

Livermore, CA 94550

415-422-2459

Gerald W. Braun

DOE

600 E Street NW

Washington, DC 20545

202-376-1934

Richard W. Bruce

Aerospace Corporation

2350 El Segundo Blvd.

E1 Segundo, CA 90009

213-648-7120

James E. Calogeras

NASA Lewis Research Center

21000 Brookpark Rd.

Cleveland, $\mathrm{OH} 44135$

$216-433-4000 \times 6995$

Martin Gutstein

U. S. DOE

600 E Street NW

Washington, DC 20545

202-376-1937
Ted Dellin

Sandia Laboratories

P. 0. Box 969

Livermore, CA 94550

415-422-2564

Henry Dodd

Sandia Labs/Albuquerque

P. O. Box 5800

Albuquerque, NM 87112

505-264-5253 (FTS-475-5253)

Martin Donabedian

Aerospace Corporation

2350 El Segundo Blvd.

E1 Segundo, CA 90009

213-648-6895

Patrick J. Eicker

Sandia Livermore Laboratories

Division 8326

Livermore, CA 94550

415-532-3115

John Gahimer

DOE/STOR

600 E Street NW

202-376-4013

Judith J. Gordon

PRC Energy Analysis Co.

7600 01d Springhouse Road

McLean, VA 22101

703-893-1800

Larry H. Gordon

NASA Lewis Research Center

21000 Brookpark Rd.

Cleveland, $\mathrm{OH} 44135$

$216-433-4000 \times 6862$

Lee G. Radosevich

Sandia Livermore Laboratories

P. 0. Box 969

Livermore, CA 94.550

415-422-2648 
Robert W. Hughey

U. S. DOE

1333 Broadway

Oakland, CA 94612

415-273-4263

Joseph J. Iannucci

Sandia Livermore Laboratories

Box 969

Livermore, CA 94550

415-422-2140

T. S. Jayadev

SERI

1536 Cole Blvd.

Golden, CO 80401

303-234-7210

George M. Kaplan

DOE

Div. of Solar Technology

Washingtion, DC 20545

202-376-1935

Frank Kreith

SERI

1536 Cole Blvd.

Golden, CO 80401

303-234-7109

William J. Masica

NASA Lewis Research Center

21000 Brookpark Rd.

Clevel and, OH 44135

216-433-4000, X 6862

Walter C. Melton

Aerospace Corporation

P. O. Box 92957

Los Angeles, CA 90009

213-648-6193, X 6862

Yong S. Won

JPL

4800 Oak Grove Dr. .

Pasadena, CA 91103

213-577-9233

Charles E. Wyman

SERI

1536 Cole Blvd.

Golden, Co 80401

303-234-7128
Robert A. Randa11

Sandia Laboratories

Kirt.l and Air korce Base

Albuquerque, NM 87110

505-264-7942

James E. Ranne1s

U. S. DOE

600 E street NW

Washington, DC 20545

202-376-1939

Thomas R. Schneider

EPRI

3412 Hillview Ave.

Palo Alto, CA 94303

415-855-2549

James H. Scott

Sandia Laboratories

Kirtland Air Force Base

Albuquerque, NM 87110

505-264-8031

Vincent Truscello

JPL

Mail Stop 502-201C

4800 Oak Grove Dr.

Pasadena, CA 91103

213-577-9367

Robert H. Turner

JPL

4800 Oak Grove Dr.

Pasadena, CA 91103

213-577-9211

Karl Wally

Sandia Laboratories

P. 0. Box 5800

Albuquerque, NM 87115

505-264-8573

Richard C. Wayne

Sandia Livermore Laboratories

Livermore, CA 94566

415-455-2711

James B. Woodard

Sandia Livermore Laboratories

Division 8326

Livermore, CA 94550

415-422-2049 